\title{
Long distance breeding dispersal of a southern elephant seal
}

\author{
Ryan R. Reisinger and Marthán N. Bester
}

Mammal Research Institute, Department of Zoology and Entomology, University of Pretoria, Pretoria, 0002, South Africa

* Corresponding author: rrreisinger@zoology.up.ac.za

\section{ABSTRACT}

Southern elephant seals range extensively during regular foraging excursions. Despite this they are highly philopatric and long range dispersal is rare. At Gough Island, southern Atlantic Ocean, we observed a breeding adult male elephant seal during September 2009 which had been tagged on its natal beach at Marion Island, southern Indian Ocean, in November 1998. The individual was resighted only once on Marion Island - six months after tagging. This 3,860 km movement represents dispersal (and likely gene flow) between distinct populations from different elephant seal geographical provinces. Given the polygynous breeding system of this species, the presence of this single male may have a disproportionate genetic effect on the small number of southern elephant seals breeding at Gough Island.

\section{KEYWORDS}

Natal dispersal; gene flow; emigration; movement; Mirounga leonina; Marion Island; Gough Island; Southern Ocean 
Southern elephant seals, Mirounga leonina, have a circumpolar distribution with breeding populations mainly concentrated on the sub-Antarctic islands (Ling and Bryden 1992). Four distinct populations or provinces are recognized: the Macquarie population in the southern Pacific Ocean, the Kerguelen population in the southern Indian Ocean, the Peninsula Valdés population in Argentina and the South Georgia population in the southern Atlantic Ocean (Slade et al. 1998; Hoelzel et al. 2001). The main breeding colonies for these populations are located on Macquarie Island, Îles Kerguelen and Heard Island, Peninsula Valdés, and South Georgia Island, respectively (Fig. 1; McMahon et al. 2005).

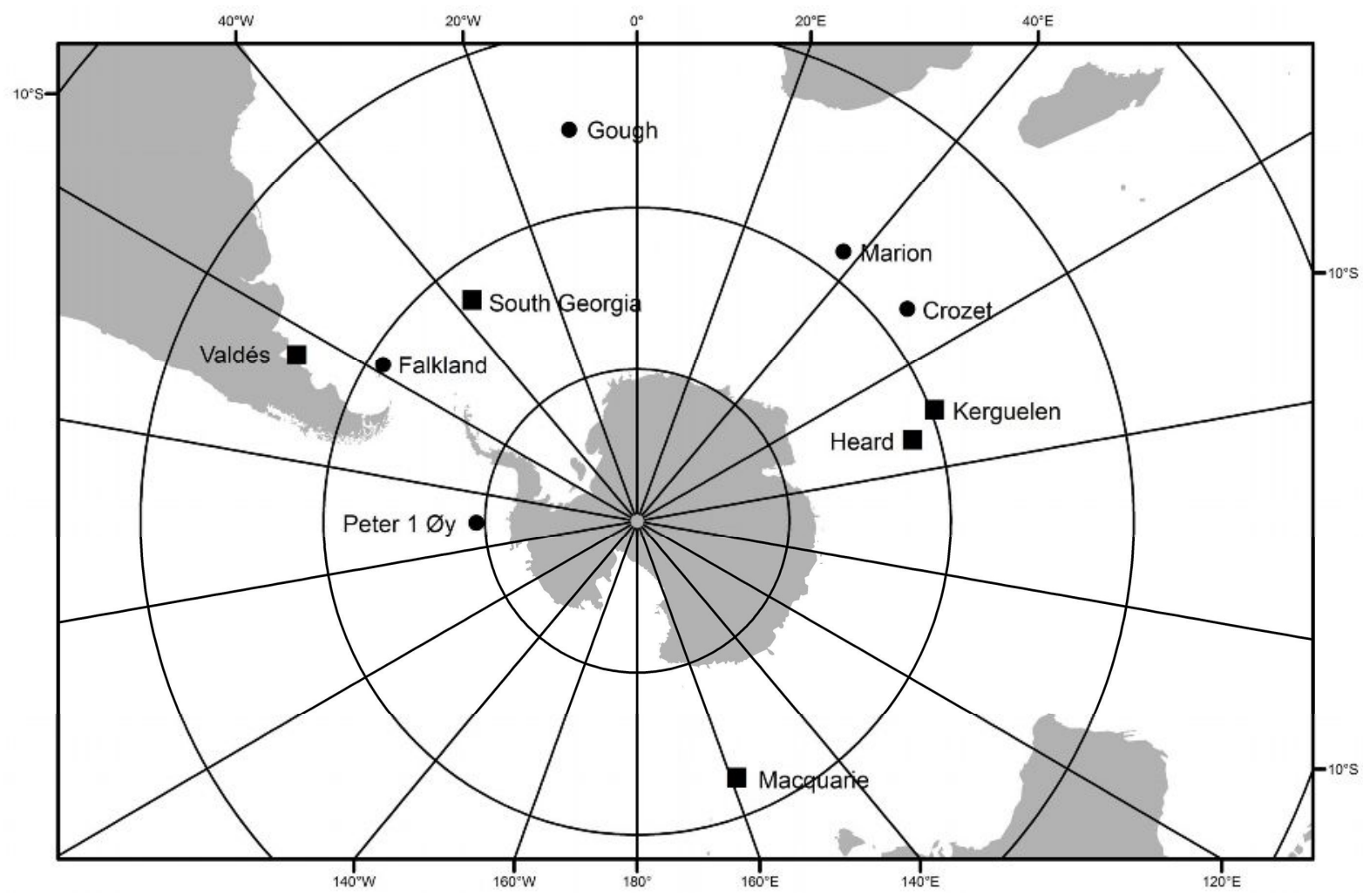

Fig. 1

Map of the Southern Ocean and surroundings, showing the locations ( $\boldsymbol{\square}$ ) of major breeding colonies in each southern elephant seal population, as well as other locations (0) mentioned in the text, including Marion Island and Gough Island

Forming part of the Kerguelen population, colonies at Marion Island (Fig. 1) numbered about 1,326 individuals in 1997, with an annual pup production of 421 (Pistorius et al. 1999). After a decline and subsequent stabilization, numbers appear to be increasing and current pup production is approximately 520 (McMahon et al. 2009; Mammal Research Institute, unpublished data). Gough Island (Fig. 1), in the southern Atlantic Ocean, 
Reisinger and Bester - Long distance breeding dispersal of a southern elephant seal

supports a small (pup production of 11 in 1997), declining number of elephant seals (Bester et al. 2001). Geographically, Gough Island forms part of the South Georgia province, although no genetic samples have been collected there.

The mating system of elephant seals is highly polygynous with females aggregating in often large groups (harems), guarded and mated by adult males at ratios (females:males) varying from 9:1 (Wilkinson and van Aarde 1999) to 277:1 (Carrick et al. 1962), depending on the locality. Both sexes are philopatric (Lewis et al. 1996; Hofmeyr 2000; Fabiani et al. 2006) but, as is common in mammals (Greenwood 1980) and documented for several marine mammals (e.g., Palumbi and Baker 1994; Escorza-Treviño and Dizon 2000; Herreman et al. 2009), dispersal in elephant seals is male-biased (van den Hoff 2001, see also Lewis et al. 1996; Slade 1997; Hoelzel et al. 2001). Elephant seals cover great distances during their foraging trips, travelling hundreds to thousands of kilometres annually (e.g., Jonker and Bester 1998; Bradshaw et al. 2004; Tosh et al. 2009). The longest recorded movement is of a juvenile female sighted on Peter $1 \varnothing y$ (Peter the First Island) after being branded on Macquarie Island, approximately 5,200 km away (Fig. 1). The female was subsequently resighted on Macquarie Island 88 days later (Hindell and McMahon 2000). Despite their regular long distance excursions from their breeding grounds, long distance dispersal is uncommon (van den Hoff 2001), an idea supported by genetic studies (Slade et al. 1998; Hoelzel et al. 2001). However, rarely, individuals may move between provinces. Fabiani et al. (2003), for example, provided evidence for male-mediated genetic dispersal over a range of about 8,000 km, from Macquarie Island to the Falkland Islands.

Several times during a survey of the small breeding population of southern elephant seals on Gough Island in September/October 2009 we sighted an adult male southern elephant seal which had been tagged on Marion Island 11 years previously. We first sighted the individual - heavily scarred from contests with other males but in good physical condition - on 29 September 2009 near Wild Glen in Hawkins Bay on the Island's north east coast. It carried Dalton Jumbotags ${ }^{\circledR}$ (Dalton Supplies Ltd., Henley-on-Thames, U.K.) in the inner-interdigital webbing of each hindflipper. We photographed these and were able to confirm the tag type as well as the tag colour and three digit tag number from the photographs. On 30 September we were able to closely approach the resting individual to examine the tags, which carried the inscription "MARION IS" on their inner surface. The tag type, inscription, unique number and colour combination (PO138) and position in the individual's 
Reisinger and Bester - Long distance breeding dispersal of a southern elephant seal

flippers unequivocally identified the individual as a male tagged on 3 November 1998 at Sealer's Cave Beach, Marion Island (approximately 3,860 km away), soon after weaning. The animal was resighted on Marion Island only once ( 6 months after tagging, for a resting haulout approximately $1.5 \mathrm{~km}$ from its natal site), despite the ongoing extensive monitoring and tagging programme at the Island (de Bruyn et al. 2008), and therefore possibly emigrated to Gough Island as a juvenile seal. Very few surveys have been conducted of elephant seals at Gough Island (Bester et al. 2001) and only a few animals have been tagged there in the 1970s (Condy and Bester 1975), no tagged elephant seals from other localities have previously been resighted there.

During our survey of elephant seal breeding sites at Gough Island from 28 September - 2 October, only 14 elephant seals were recorded: six adult males and six adult females (two of which were nursing pups), sparsely distributed along the coast. Our survey preceded the peak breeding haulout of female elephant seals there (Bester 1980) by about two weeks. When we first encountered the Marion Island male, it was resting near two females with one other male nearby. The Marion male later moved to a site unoccupied by females, where it was chased from the beach by another male. Subsequently the Marion male was seen resting with two females, with no other male nearby. No copulation was observed as our survey was relatively early in the breeding season at this locality and males attempt copulation only when females enter oestrus in the last 2-3 days of the 23 day nursing period (Laws 1956). Most males were observed moving up and down the section of coast where females were distributed, probably in an attempt to establish dominance at a breeding site before the onset of oestrus in most females.

During the ongoing elephant seal monitoring and tagging programme at Marion Island (de Bruyn et al. 2008), a number of animals tagged there have been resighted at other localities, and vice-versa (Bester 1989; Oosthuizen et al. 2009; Mammal Research Institute, unpublished data) including several dispersal records between Marion Island and Îles Crozet (Fig. 1). The latter represent dispersal within the Kerguelen population. Our study describes what appears to be an uncommon phenomenon in elephant seals: dispersal between different elephant seal populations or provinces (Kerguelen and South Georgia populations, although elephant seals at Gough Island have not been genetically grouped within the South Georgia population). While we could not observe copulation, even mating with a small number of females would represent a substantial genetic contribution to the elephant seal population at Gough Island and thus potentially instigate a strong 
homogenising effect on the Gough Island population (see Fabiani et al. 2003). The persistence of the tiny Gough Island population - a sink population in a metapopulation framework (Clobert et al. 2001) - may well depend on such dispersal events.

\section{ACKNOWLEDGEMENTS}

Logistical support at Gough Island was provided by the South African Department of Environmental Affairs through the South African National Antarctic Programme. Research at Gough Island is conducted with the permission of the Administrator and Island Council of Tristan da Cunha. Trevor Glass, Head of Tristan Conservation Department, and his assistant, Norman Glass, are thanked for their encouragement. John van den Hoff, Alejandro Carlini, Chris Oosthuizen, Trevor Mclntyre and Nico de Bruyn made useful comments on this manuscript.

\section{REFERENCES}

Bester MN (1980) The southern elephant seal Mirounga leonina at Gough Island. S Afr J Zool 15: 235-239

Bester MN (1989) Movements of southern elephant seals and Subantarctic fur seals in relation to Marion Island. Mar Mamm Sci 5:257-265

Bester MN, Möller H, Wium J, Enslin B (2001) An update on the status of southern elephant seals at Gough Island. S Afr J Wildl Res 31: 68-71

Condy PR, Bester MN (1975) Notes on the tagging of seals at Marion and Gough Islands. S Afr J Antarct Res 5 : 45- 47

Bradshaw CJA, Hindell MA, Sumner MD, Michael KJ (2004) Loyalty pays: potential life history consequences of fidelity to marine foraging regions by southern elephant seals. Anim Behav 68:1349-1360

Carrick R, Csordas SE, Ingham SE (1962) Studies on the southern elephant seal, Mirounga leonina (L.) IV. Breeding and development. CSIRO WildI Res 7:61-197

Clobert J, Danchin E, Dhondt AA, Nichols JD (2001) Dispersal. Oxford University Press, New York 
Reisinger and Bester - Long distance breeding dispersal of a southern elephant seal

de Bruyn PJN, Tosh CA, Oosthuizen WC, Phalanndwa MV, Bester MN (2008) Temporary marking of unweaned southern elephant seal (Mirounga leonina L.) pups. S Afr J Wildl Res 38:133-137

Escorza-Treviño S, Dizon AE (2000) Phylogeography, intraspecific structure and sex-biased dispersal of Dall's porpoise, Phocoenoides dalli, revealed by mitochondrial and microsatellite DNA analyses. Mol Ecol 9:1049-1060

Fabiani A, Galimberti F, Sanvito S, Hoelzel AR (2006) Relatedness and site fidelity at the southern elephant seal, Mirounga leonina, breeding colony in the Falkland Islands. Anim Behav 72:617-626

Fabiani A, Hoelzel AR, Galimberti F, Muelbert MMC (2003) Long-range paternal gene flow in the southern elephant seal. Science 299:676

Greenwood PJ (1980) Mating systems, philopatry and dispersal in birds and mammals. Anim Behav 28:11401162

Herreman JK, Blundell GM, McDonald DB, Ben-David M (2009) Asymmetrical male-mediated gene flow between Harbor seal (Phoca vitulina) populations in Alaska. Can J Zool 87:498-507

Hindell MA, McMahon CR (2000) Long distance movement of a southern elephant seal (Mirounga leonina) from Macquarie Island to Peter $1 \varnothing y$. Mar Mamm Sci 16:504-507

Hoelzel AR, Campagna C, Arnbom T (2001) Genetic and morphometric differentiation between island and mainland southern elephant seal populations. P R Soc B 268:325-332

Hofmeyr GJG (2000) Dispersal and dispersion of southern elephant seals at Marion Island. MSc Dissertation, University of Pretoria, Pretoria, South Africa

Jonker FC, Bester MN (1998) Seasonal movements and foraging areas of adult southern female elephant seals, Mirounga leonina, from Marion Island. Antarct Sci 10:21-30

Laws RM (1956) The elephant seal (Mirounga leonina Linn.), III: the physiology of reproduction. Sci Rep Falkland Is Dep Surv 15:1-66

Lewis M, Campagna C, Quintana F (1996) Side fidelity and dispersion of southern elephant seals from Patagonia. Mar Mamm Sci 12:138-147

Ling JK, Bryden MM (1992) Mirounga leonina. Mamm Species 391:1-8 
Reisinger and Bester - Long distance breeding dispersal of a southern elephant seal

McMahon CR, Bester MN, Burton HR, Hindell MA, Bradshaw CJA (2005) Population status, trends and a reexamination of the hypotheses explaining the recent declines of the southern elephant seal Mirounga leonina. Mammal Rev 35:82-100

McMahon CR, Bester MN, Hindell MA, Brook BW, Bradshaw CJA (2009) Shifting trends: detecting environmentally mediated regulation in long-lived marine vertebrates using time-series data. Oecologia 159:69-82

Oosthuizen WC, Bester MN, de Bruyn PJN, Hofmeyr GJG (2009) Intra-archipelago moult dispersion of southern elephant seals at the Prince Edward Islands, southern Indian Ocean. Afr J Mar Sci 31:457-462

Palumbi SR, Baker CS (1994) Contrasting population structure from nuclear intron sequences and mtDNA of humpback whales. Mol Biol Evol 11:426-435

Pistorius PA, Bester MN, Kirkman SP (1999) Dynamic age-distributions in a declining population of southern elephant seals. Antarct Sci 11:445-450

Slade RW (1997) Genetic studies of the southern elephant seal, Mirounga leonina. In: Hindell M, Kemper C (eds) Marine mammal research in the southern hemisphere, volume 1: status, ecology and medicine. Surrey Beatty and Sons, Chipping Norton, Australia, pp 11-29

Slade RW, Moritz C, Hoelzel AR, Burton HR (1998) Molecular population genetics of the southern elephant seal Mirounga leonina. Genetics 149:1945-1957

Tosh CA, Bornemann H, Ramdohr S, Schröder M, Martin T, Carlini A, Plötz J, Bester MN (2009) Adult male southern elephant seals from King George Island utilize the Weddell sea. Antarct Sci 21:113-121

Van den Hoff J (2001) Dispersal of southern elephant seals (Mirounga leonina L.) marked at Macquarie Island. Wildl Res 28:413-418

Wilkinson IS, van Aarde RJ (1999) Marion Island elephant seals: the paucity-of males hypothesis tested. Can J Zool 77:1547-1554 